\title{
УАK 338.439:631.4-049.5
}

\author{
А. В. Переверзєва, \\ А. е. н., Аоцент, професор кафедри міжнародної економіки, природних ресурсів \\ та економіки міжнародного туризму, Запорізький національний університет \\ ORCID ID: 0000-0001-8391-6636
}

\section{В. П. Волков,} А. т. н., професор, професор кафеАри підприємництва, менеАжменту організацій та логістики, Запорізький національний університет

ORCID ID: 0000- 0002-1270-895X

B. O. $\Lambda я x$,

А. б. н., професор, професор кафедри генетики та рослинних ресурсів, Запорізький національний університет ORCID ID: 0000-0002-4381-6566

\section{ВПАИВ АЕГРАААЦІЇ ГРУНТІВ НА ПРОАОВОАЬЧУ БЕЗПЕКУ}

\author{
A. Pereverzieva, \\ Doctor of Economic Sciences, Associate Professor, Professor of the Department of International Economy, \\ Natural Resources and Economics International Tourism, Zaporizhzhia national university \\ V. Volkov, \\ Doctor of Technical Sciences, Professor, Professor of the Department of Entrepreneurship, \\ Management of Organizations and Logistics, Zaporizhzhia national university \\ V. Lyakh, \\ Doctor of Biological Sciences, Professor, Professor of the Department of genetics and plant resources, \\ Zaporizhzhia national university
}

\section{IMPACT OF SOIL DEGRADATION ON FOOD SECURITY}

У статті досліджується вплив рівня деградації грунтів на продовольчу безпеку людства. Обгрунтовано, що збільшення кількості населення посилює темпи зростання попиту на продукти харчування, що своєю чергою потребує забезпечення високої якості грунтів. Разом із тим із збільшенням рівня деградації грунтів зменшується рівень продовольчої безпеки внаслідок неможливості задоволення зростаючого попиту населення на продукти харчування. Аоведено, що темпи зростання населення у країнах із низьким рівнем доходу на душу населення $є$ вищими, ніж у країнах, що розвиваються. Спостерігається така залежність: чим біднішою $є$ країна, тим вищим $є$ технологічний тиск на землю та на рівень деградації грунтів. Визначено, що за останні 150 років деградація грунтів призвела до зниження врожайності на 25-50\% у деяких регіонах Європи та Північної Америки. В Азії, особливо в Індії, Китаї, Ірані, Ізраїлі, Йорданії, $\Lambda$ івані, Непалі та Пакистані спостерігаються значні втрати продуктивності врожаїв - до 20\%. Водночас гранична деградація може зменшити врожайність на $10 \%$, помірна - від $10 \%$ до 50\%. Значно деградований грунт може знизити врожайність культури понаА $50 \%$. Обгрунтовано, що головним завданням аграріїв у світовому вимірі до 2050 року є забезпечити продуктами харчування додатково $1,7-2,3$ млрд осіб за одночасного зростання рівня деградації грунту та підвищений ризик зміни клімату, що на сучасному етапі є головним викликом Аля АюАство. Виникає небезпечна ситуація, за якої зростання кількості населення та деградація грунтів призводять до Аефіциту проАуктів харчування та загрожують продовольчій безпеці людства. Аля того щоб прогодувати орієнтовно 9,1 млрд населення світу у 2050 році, потрібно збільшити загальне виробництво продуктів харчування приблизно на $70 \%$. Виробництво сільськогосподарської продукції в країнах, що розвиваються, повинно зростати швидше. Прогнозна оцінка показує, що важливою проблемою $є$ дефіцит робочої сили у сільському господарстві. Економічна прибутковість також є основним обмеженням у виробництві продуктів харчування в розвинутих країнах. На основі побудованого прогнозу рівня деградації грунтів та, враховуючи той факт, що грунти забезпечують $98 \%$ продуктів харчування, визначено, що до 2100 р. рівень забезпечення продуктами харчування за рахунок грунтів знизиться на $48 \%$ внаслідок їх 
Аеградації і складе $50 \%$, тобто рівень продовольчої безпеки скоротиться на $50 \%$, що означає зменшення рівня наполовину забезпечення населення світу продуктами харчування. Обгрунтовано, що потребує вирішення питання запровадження ефективного економічного механізму управдіння дефіцитними ресурсами на правових засадах.

Impact of soil degradation on human food security has been studied in the article. It has been proved that the population growth increases the demand for food surge, which in turn requires high quality soils support. At the same time, higher soil degradation decreases food security due to the inability to meet the growing demand of the population for food. It has been confirmed that population growth rates in countries with low per capita income are higher than in developing countries. There is the next correlation: the poorer the country, the higher the anthropogenic pressure on the land and soil degradation. It has been determined that over the last 150 years, soil degradation has led to $25-50 \%$ decline in the crop yield in some regions of Europe and North America. In Asia, especially in India, China, Iran, Israel, Jordan, Lebanon, Nepal and Pakistan, there are significant losses in crop productivity - up to $20 \%$. In this case, marginal degradation can reduce crop yield by $10 \%$, moderate - from $10 \%$ to $50 \%$. Significant soil degradation can reduce crop yield by more than $\mathbf{5 0 \%}$. It has been demonstrated that farmers 'main task globally by $\mathbf{2 0 5 0}$ is to provide food to additional $1.7-2.3$ billion people amid increasing soil degradation and higher risk of climate change as current key challenges for the humanity. There is a dangerous situation of population growth and soil degradation leading to food shortages and food security threats. To feed $\mathbf{9 . 1}$ billion people around the world in $\mathbf{2 0 5 0}$, it is necessary to boost total food production by about $70 \%$. Agricultural production in developing countries must grow faster. The forecast shows that the hot button problem is labour shortage in agriculture. Economic profitability is also a major constraint on food production in the developed countries. Based on the forecast of soil degradation and taking into account that soils provide $98 \%$ of food, it has been determined that by 2100 the food supply provided by soils will decrease by $48 \%$ due to their degradation and will reach $50 \%$, i.e. the level of food security will contract at $50 \%$ which means halving the world's food supply. It is substantiated that the issue of introduction of an effective economic mechanism for managing scarce resources on a legal basis needs to be addressed.

Ключові слова: деградачія грунтів, продовольча безпека, населення, родючість грунтів, дефічит, глобальна проблема.

Key words: soil degradation, food security, population, soil productivity, shortage, global issue.

\section{ПОСТАНОВКА ПРОБЛЕМИ}

У останні десятиліття проблема продовольчої безпеки загострюється, що пов'язано із підвищенням темпів зростання кількості населення, та, відповідно, супроводжується зростанням споживчого попиту за одночасного скорочення кількості земель, придатних для сільськогосподарського використання з метою задоволення потреб людства в продовольстві. У зв'язку із цим виникає загроза продовольчій безпеці в майбутньому, що обумовлює необхідність пошуку раціональних способів вирішення проблеми забезпечення населення світу життєвими благами за рахунок підвищення ефективності використання наявних ресурсів тривалого зберігання і використання та застосування позитивних практик провідних країн світу й Європи. Одним із дієвих механізмів вирішення зазначеної проблеми $є$ уповільнення темпів деградації грунтів, їх впливу на продовольчу безпеку людства та побудова прогнозу масштабів скорочення кількості земель, придатних для ведення господарської діяльності.

\section{АНАЛІЗ ПОПЕРЕДНІХ ДОСЛІДЖЕНЬ}

Значну увагу проблемі продовольчої безпеки приділяють як міжнародні інституції, так і українські вчені. Серед міжнародних організацій вагомий внесок у розвиток визначеної проблематики зробили ФАО [1] та ООН [2]. Українські вчені О. Зеленська [3], О. Гойчук [4], Ю. Аузан [5], Б. Пасхавер [6], П. Саблук [7] аналізували теоретичні підходи до визначення поняття "продовольча безпека", чинники, котрі впливають на неї та показники оцінки порогового значення рівня продовольчої безпеки, перевищення якого $є$ загрозою для розвитку країни в майбутньому. Проблема деградації грунтів глибоко досліджується в працях В. Медведева [8], I. Пліско [9], А. Кучера [10; 11] та інших. Значна кількість наукових праць та прикладних досліджень є базою для визначення впливу наслідків деградації грунтів на продовольчу безпеку в світі.

\section{META CTATTI}

Метою статті є з'ясування впливу деградації грунтів на світову продовольчу безпеку в 
світі задля впровадження превентативної політики щодо раціонального землекористування, відтворення та охорони грунтів.

\section{РЕЗУЛЬТАТИ ДОСЛІДЖЕННЯ}

За міжнародними дослідженнями до 2030 р. будуть спостерігатися дві мегатенденції: демографічні проблеми - збільшення чисельності населення світу, зростання потреби в продуктах харчування, що може призвести до більш жорсткого дефіциту ресурсів. Збільшення пропиту на продукти харчування разом із зміною клімату створюють незворотний вплив на розвиток світової економіки на найближчі $15-20$ років. За рахунок збільшення кількості населення попит на ресурси зросте з 7,1 млрд дол США у 2019 р. до 8,3 млрд дол США у 2030 р. Як зазначають дослідники "...зростання середнього класу та цілеспрямована урбанізація посилюють тиск на дефіцитні ресурси - переважно на продовольство" [12].

Підкреслимо, земельні ресурси є основним джерелом життєдіяльності людства. Протягом останніх семи десятиліть унаслідок значного збільшення кількості населення, зростання доходу на душу населення, зміни смаків відбувається зростання попиту на продовольство. Значну кількість землі сільськогосподарського призначення було втрачено через активізацію будівництва житла, доріг та вдосконалення інфраструктури. Одночасно, в результаті інтенсивного землеробства, вирубки лісів, забруднення водних ресурсів і збільшення використання хімічних добрив та пестицидів, верхній грунт значно деградував, що виявляється в підвищеному рівні засолення, втраті родючості, ерозії грунту та спустошення. Значне зростання споживання прісної води, забруднення річок, озер і скидання значної кількості промислових відходів у водойми прискорює процес деградації грунту. Часті посухи та повені, інші форми екстремальних погодних умов внаслідок глобального потепління та зміни клімату також призводять до активного процесу деградації грунту. Зниження якості земель відбувається також унаслідок діяльності людей, залишається головною причиною і викликає серйозне занепокоєння та головну глобальну проблему через несприятливий вплив на виробництво продуктів харчування, навколишнє середовище та засоби існування.

Тривала деградація земель може призвести до тимчасового або постійного зниження родючості грунтів. Посуха, повені, надмірне використання хімічних речовин, втрата поживних речовин, інтенсивне та нестійке землеробство, вирубка лісів, урбанізація, забруднення води, збільшення кількість твердих відходів та їх утилізація вважаються одними з найважливішими причин утворення земельної деградації. Ауже часто одні негативні фактори призводить до інших, що викликає ланцюгову реакцію. Наприклад, вирубка лісів призводить до підтоплення та водної ерозії грунтів.

Отже, причини деградації земель є складними, і взаємопов'язаними і багатовекторними. Відповідно до даних ФАО [1], деградація земель визначається як зміна стану грунту, що призводить до погіршення характеристик екосистем для забезпечення виробництва товарів та надання послуг. Таким чином, деградація земель передбачає фактичну або потенційну втрату продуктивності через надмірну експлуатацію; невідповідність між якістю грунту та інтенсивністю його використання, індуковані людиною фізичні, біологічні та хімічні процеси та природні небезпеки.

Хоча оцінки деградації земель та їх інтенсивність коливаються в широких межах від $35 \%$ до 55 \%, вважається, що рівень деградації земель є помірними. Такі розбіжності є природними, враховуючи той факт, що не існує точного загальновизнаного визначення терміну для деградації земель. Більше того, величину та інтенсивність деградації оцінити складно, незважаючи на розробку нових наукових методів. Більшість цих оцінок базується на індивідуальних та інституційних дослідженнях у межах визначених параметрів, як-от: ерозія, втрата поживних речовин, засолення тощо.

За даними Глобальної оцінки деградації грунтів 35 \% ріллі в світі вже деградували. Цей процес продовжується до теперішнього часу. Аише інтенсивне сільське господарство призводить до ерозії та засолення 6 млн га на рік [1].

У світовому масштабі з 1945 р. кількість грунтів, що вже деградували, еквівалентно за розміром території Китаю та Індії разом, тобто щорічно втрачається 24 млрд т верхнього шару грунту, що складає площу біля 9,6 млн га землі. У всьому світі понад $20 \%$ оброблюваних площ, 30\% лісів та 10\% відповідно мають різний ступінь деградації, що негативно впливає на життєдіяльність близько 1,5 млрд людей.

Аеградація земель є сукупним результатом впливу низки факторів, серед яких неефективні практики землекористування, вирубка лісів, ерозія грунту та зміна кліматичних умов.

Світова комісія з охорони навколишнього середовища та розвитку (WCED) дотримується думки, що недалекоглядна аграрна політи- 


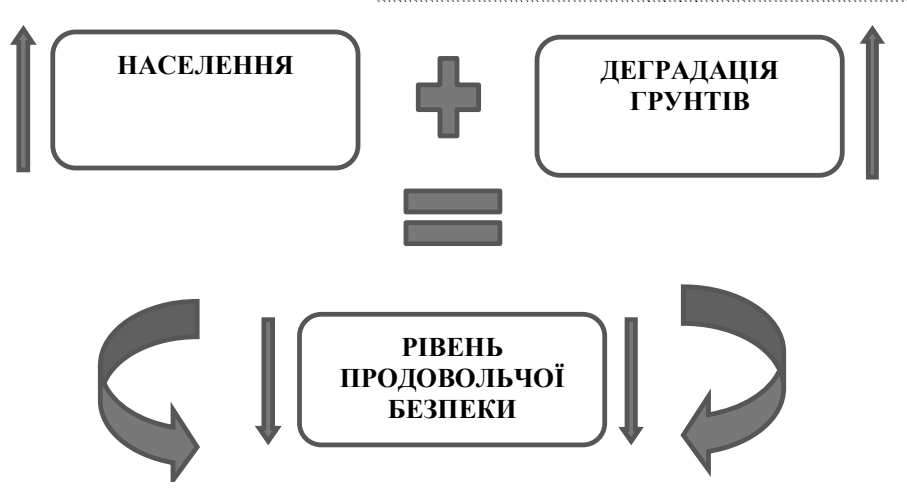

\section{Рис. 1. Вплив населення та деградації грунтів} на продовольчу безпеку

Ажерело: побудовано авторами самостійно.

ка, передбачена політикою та надмірним антропогенним тиском на землю призводять до деградації земель майже на всіх континентах: ерозія грунту в Північній Америці; засолення грунту в Європі; вирубка лісів та спустошення в Азії, Африці, Аатинській Америці.

За даними WCED [15] перетворення лісів та природних пасовищ на землях сільськогосподарського призначення, перехід від природної рослинності до інтенсифікації вирощування товарних культур, як-от кава, бавовна, сільськогосподарські поля для вирощування та перехід від природної рослинності до інтенсивних товарних культур, таких як пальмова олія, соя та пшениця. Це призвело до посилення ерозії грунту за межі здатності грунту гнучко пристосовуватися та підтримувати себе. Крім того, на якість грунту також впливали втрата структури грунту, дефіцит поживних речовин та солоність грунту.

За даними WCED [15] половина верхнього шару грунту на планеті була втрачена за останні 150 років Світове ущільнення грунту є проблемою у всьому світі, особливо з прийняттям механізованого сільського господарства. Ущільнення грунту призвело до зниження врожаю на $25-50 \%$ у деяких регіонах Європи та Північної Америки. В Азії, особливо в Індії, Китаї, Ірані, Ізраїлі, Йорданії, Аівані, Непалі та Пакистані спостерігаються значні втрати продуктивності до $20 \%$, спричинені ерозією грунту.

Гранична деградація може зменшити врожайність на $10 \%$, помірна - від $10 \%$ до $50 \%$ /. Значно деградований грунт може знизити врожайність культури понад 50\%. Стихійні лиха, як-от: повені та зсуви частіше виникають через деградацію грунтів.

Суттєвим наслідком деградації грунтів $є$ зниження рівня продовольчої безпеки.

Тобто на сучасному етапі знижується рівень продовольчої безпеки внаслідок зміни кліма- тичних умова та деградації природних ресурсів, ключовим із яких щодо задоволення потреб населення у продуктах харчування є земля. Взаємозв'язок кількості населення, рівня деградації грунтів та продовольчої безпеки можна представити схематично (рис. 1).

На рисунку 1 продемонстровано, що при зміні кількості населення, зростає попит на продукти харчування, що забезпечується за рахунок високоякісних грунтів. Своєю чергою підвищення рівня деградації грунтів обумовлює неможливість задоволення потреб населення, наслідком є зниження рівня продовольчої безпеки.

За даними ФАО біля $97 \%$ продуктів харчування забезпечується за рахунок земельних ресурсів. Значні темпи зростання населення світу призводить до збільшення попиту на продукцію сільського господарства. Глобальна чисельність населення в 1900 р. оцінювалася в 1,65 млрд осіб, 2016 р. - 7,4 млрд осіб. Організація Об'єднаних Націй підрахувала, що чисельність населення світу ще зросте як мінімум до 9,1 млра осіб у 2050 р. і до 11,2 млрд у 2100 р. [2]. Водночас темпи зростання населення у країнах із низьким рівнем доходу на душу є вищими, ніж у країнах, що розвиваються.

Найбільш населеними країнами світу є: Бангладеш, Бразилія, Китай, Індія, Індонезія, Мексика, Нігерія, Пакистан, Російська Федерація та Сполучені Штати Америки. Ці 10 країн із загальною чисельністю населення 4,4 млрд осіб становлять майже $60 \%$ світового населення.

Головним завданням до 2050 року є забезпечити продуктами харчування додатково 1,72,3 млрд осіб із збільшенням деградації грунту та постійне зростання ризику зміни клімату, що на сучасному етапі $є$ головним викликом для людства. Підкреслимо, що прогнози ФАО [1] доводять, щоб забезпечити 9,1 млрд населення світу у 2050 році, потрібно збільшити загальне 
Таблиця 1. Прогноз деградації грунтів на 2030-2100 рр.

\begin{tabular}{|c|c|c|c|c|c|c|c|c|}
\hline \multirow{2}{*}{ Показники } & \multicolumn{8}{|c|}{ Глибина прогнозу, роки } \\
\hline & \multicolumn{2}{|l|}{2019} & \multicolumn{2}{|l|}{2030} & \multicolumn{2}{|c|}{\begin{tabular}{l|l}
2050 &
\end{tabular}} & 2100 & \multirow{3}{*}{$\frac{2100 / 2019}{1,48(48 \%)}$} \\
\hline Деградація & 2 & 1,06 & 2,12 & 1,11 & 2,36 & 1,25 & \multirow[t]{2}{*}{2,96} & \\
\hline млрд га & & & & & & & & \\
\hline $\begin{array}{c}\text { Населення, } \\
\text { млрд осіб }\end{array}$ & 7,7 & 1,10 & 8,5 & 1,14 & 9,7 & 1,15 & 11,2 & $1,45(45 \%)$ \\
\hline $\begin{array}{c}\text { Обсяг } \\
\text { деградації } \\
\text { грунтів } \\
\text { /особу, } \\
\text { млрд га }\end{array}$ & 0,260 & & 0,249 & & 0,243 & & 0,264 & $\begin{array}{c}0,001 \\
(0,1 \%)\end{array}$ \\
\hline
\end{tabular}

Ажерело: розроблено авторами за даними: [1-2; 13-14].

виробництво продуктів харчування приблизно на $70 \%$.

Важливою проблемою є дефіцит робочої сили у сільському господарстві. Економічна прибутковість також є одним із основних обмежень у виробництві продуктів харчування в розвинутих країнах.

Аналіз досліджень масштабів деградації грунтів та їх ролі в досягненні необхідного рівня продовольчої безпеки дозволив виокремити індикатори, котрі є базою для прогнозування:

1) 2019 р. - деградація грунтів 2 млрд га;

2) щорічно деградує 12 млн га;

3 ) грунти забезпечують отримання 98\% продуктів харчування.

Побудова прогнозу дає можливість визначити рівень продовольчої безпеки в світі на основі передбачення рівня деградації грунтів у майбутньому. За статистикою деградації грунтів у 2019 р., щорічних показників обсягів деградації та змінами кількості населення, нами побудовано прогноз на період 2030-2100 р. (табл. 1).

У 2100 році рівень деградації грунтів може складати 48\% від загальної кількості порівняно із 2019 р. Враховуючи той факт, що грунти забезпечують 98\% продуктів харчування, до 2100 р. рівень забезпечення продуктами харчування за рахунок грунтів знизиться на $48 \%$ внаслідок їх деградації і складе 50\%.

Населення у 2100 році зросте на $45 \%$ порівняно з 2019 р., що означає зростання потреб у продуктах харчування на $45 \%$, i, відповідно, обумовлює необхідність підвищення родючості грунтів. Виникає небезпечна ситуація, за якої зростання кількості населення та деградація грунтів, що призводить до дефіциту продуктів харчування та загрожувати продовольчій безпеці людства.

\section{вИСНОВКИ}

На основі проведеного дослідження можна зробити висновки, що земля є багатством, що забезпечує умови для існування та розвитку людських ресурсів. Рівень деградації грунтів продовжує збільшуватися внаслідок нераціонального землекористування, зміни кліматичних умов та недбалого ставлення до навколишнього середовища. Якщо цей процес буде тривалим, то як насідок - знизиться рівень продовольчої безпеки людства, адже кількість населення світу зросте, збільшиться попит на продукти харчування, а якість земельних ресурсів не дозволить задовольнити потреби в продовольстві. Адже можливості забезпечення життєдіяльності визначаються не кількістю земельних ресурсів, а якісними характеристиками та раціональністю господарювання.

Тому вкрай важливо вжити превентивних заходів, щоб уникнути браку цих ресурсів у майбутньому. Ключовими питання, котрі потребують оперативного вирішення є: чи стане управління дефіцитними ресурсами більш ефективним, розвиток яких технологій допоможе пом'якшити проблеми з ресурсами і чи будуть застосовані відповідні правові механізми, щоб уникнути найгірших можливих наслідків.

\section{$\Lambda$ ітература:}

1. Desertification and land degradation. URL: http://www.fao.org/in-action/action-againstdesertification/overview/desertification-and-landdegradation/en/ (дата звернення 01.10.2020).

2. Land Degradation and Improvements. URL: https://www.un.org/en/events/desertification_decade/value.shtml\#a2 (дата звернення 01.10.2020).

3. Зеленська О.О. Система продовольчої безпеки: сутність та ієрархічні рівні. Вісник ЖАТУ. 2012. № 1 (59). С. 108-112.

4. Гойчук O.I. Продовольча безпека: монографія. Житомир: Полісся, 2004. 348 с.

5. Аузан Ю.Я. Перспективи створення самозабезпечувальної енергетичної системи ведення сільськогосподарського виробництва. Економіка АПК. 2010. № 4. С. 40-48.

6. Пасхавер Б.Й. Сучасний стан продовольчої безпеки. Економіка АПК. 2014. № 4. С. 5-12. 
7. Саблук П.Т., Білорус О.Г., Власов В.І. Глобалізація і продовольство: монографія. Київ: ННЦ -IAE, 2008. 632 с.

8. Медведєв В.В., Пліско І.В. Критерії і нормативи фізичної деградації орних грунтів (пропозиції до вдосконалення нормативної бази). Вісник аграрної науки. 2017. № 3. С. 11-17.

9. Пліско І.В. Аінійні та нелінійні моделі в оцінюванні якості грунтів. Таврійський науковий вісник. 2018. № 102. С. 136-142.

10. Kucher A. Estimation of effectiveness of usage of liquid organic fertilizer in the context of rational land use: a case study of Ukraine. Przeglad Wschodnioeuropejski. 2017. Vol. VIII. No. 2. Pp. 95-105. URL: https://doi.org/10.31648/pw.3573.

11. Кучер А. Оцінка впливу якості земель на конкурентоспроможність підприємств. Agricultural and Resource Economics. 2019. Vol. 5. No. 2. Pp. 99-120. URL: http://are-journal.com (дата звернення 04.09.2020).

12. Глобальные тенденции 2030: альтернативные миры. Национальный совет по разведке, 2019. 169 c.

13. Gupta G.S. Land Degradation and Challenges of Food Security Review of European Studies. Vol. 11, No. 1; 2019 ISSN 1918-7173 EISSN 1918-7181. doi:10.5539/res.v11n1p63.

14. Regional workshop fertility management through farmer field schools in the Near East. Food and Agriculture Organization of the United Nations Regional Office for the Near East, Amman, Jordan, 2-5 October 2000, 85 p.

15. Світова комісія з охорони навколишнього середовища та розвитку (WCED). URL: https://sustainabledevelopment.un.org/milestones/wced (дата звернення 01.10.2020).

\section{References:}

1. FAO (2020), "Desertification and land degradation", available at: http://www.fao.org/inaction/action-against-desertification/overview/ desertification-and-land-degradation/en/ (Accessed 01.10.2020).

2. UN (2020), "Land Degradation and Improvements", available at: https://www.un.org/en/ events/desertification_decade/value.shtml\#a2 (Accessed 01.10.2020).

3. Zelenska, O.O. (2012), "Food security system: essence and hierarchical levels", Visnyk ZhDTU, vol. 59, No 1, pp. 108-112.

4. Gojchuk, O.I. (2004), Prodovolcha bezpeka [Food security], Polissya, Zhytomyr, Ukraine.

5. Luzan, Yu. Ya. (2010), "Prospects for creating a self-sufficient energy system for agricultural production", Ekonomika APK, vol. 4, pp. 40-48.

6. Pasxaver, B. J. (2014), "The current state of food security". Ekonomika APK, No 4, pp. 5-12.
7. Sabluk, P.T. Bilorus, O.G. and Vlasov, V.I. (2008), Hlobalizatsiya I prodovolstvo [Globalization and food], NNCz -IAE?, Kyiv, Ukraine.

8. Medvedev, V.V. and Plisko, I.V. (2017), "Criteria and standards for physical degradation of arable soils (proposals for improving the regulatory framework)", Visnyk ahrarnoi nauky, vol. 3, pp. 11-17.

9. Plisko, I.V. (2018), "Linear and nonlinear models in soil quality assessment", Tavriyskiy naukovyj visnyk, vol. 102, pp. 136-142.

10. Kucher, A. (2017), "Estimation of effectiveness of usage of liquid organic fertilizer in the context of rational land use: a case study of Ukraine", Przeglad Wschodnioeuropejski, vol. VIII, No. 2, pp. 95-105. https://doi.org/10.31648/pw.3573.

11. Kucher, A. (2019), "Assessment of the impact of land quality on the competitiveness of enterprises", Agricultural and Resource Economics, vol. 5, No. 2. pp. 99-120, available at: http://are-journal.com (Accessed 01.10.2020).

12. NIC (2020), "Global Trends 2030: Alternative Worlds", available at: www.dni.gov/nic/ globaltrends (Accessed 01.10.2020).

13. Gupta, G. S. (2019), Land Degradation and Challenges of Food Security, Review of European Studies, vol. 11, No. 1. doi:10.5539/res.v11n1p63.

14. FAO (2020), Regional workshop fertility management through farmer field schools in the Near East, Amman, Jordan.

15. WCED (2020), "Report of the World Commission on Environment and Development", available at: https://sustainabledevelopment.un.org/milestones/wced (Accessed 01.10.2020). Стаття надійшла до редакиї 06.10.2020 p.

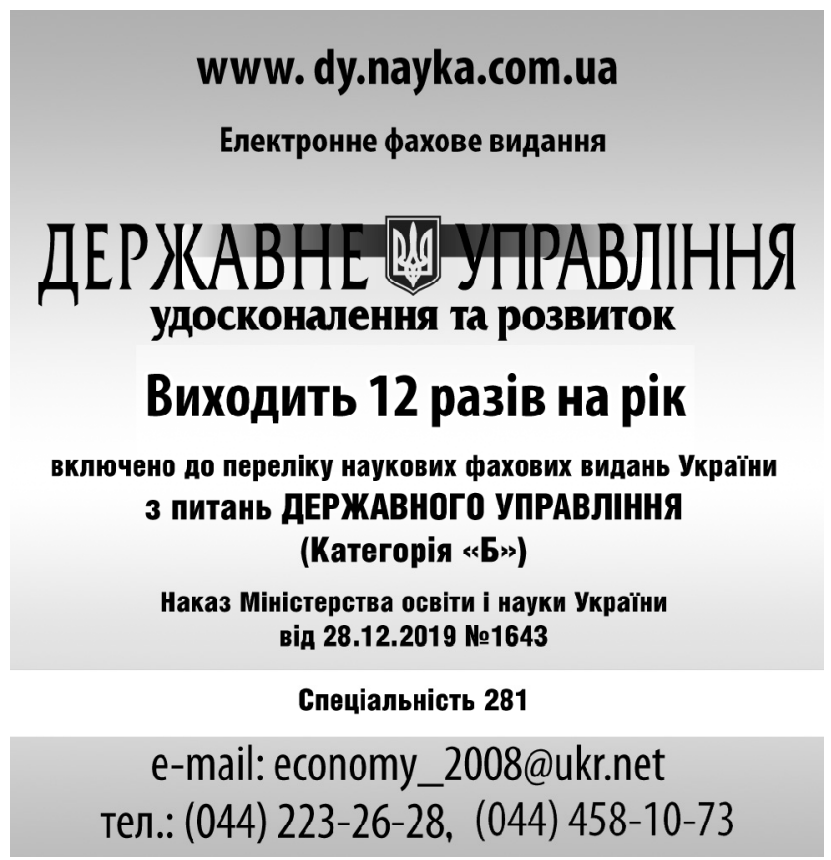

